\author{
Dr Stella KACZMAREK \\ Akademia Muzyczna w Lodzi \\ e-mail: stella.kaczmarek@amuz.lodz.pl \\ ORCID: 0000-0002-4509-5790 \\ Dr Joanna POSŁUSZNA \\ Instytut Psychologii Uniwersytet Marii Curie-Skłodowskiej w Lublinie \\ e-mail: joanna.posluszna@poczta.umcs.lublin.pl \\ ORCID: 0000-0003-2457-7456
}

DOI: $10.15290 /$ oes.2019.03.97.12

\title{
UWARUNKOWANIA FINANSOWANIA TWÓRCÓW I ARTYSTÓW W POLSCE ${ }^{1}$
}

\begin{abstract}
Streszczenie
Cel - Celem rozważań jest analiza sytuacji finansowo-ekonomicznej artystów i twórców w Polsce ze zwróceniem szczególnej uwagi na formy zatrudnienia oraz zaplecze socjalne.

Metoda badan - Artykuł ma charakter przeglądu różnych źródeł historycznych przedstawiających sytuację i uwarunkowania finansowania twórców i artystów w Polsce od $2010 \mathrm{r}$. W artykule zastosowano analizę krytyczną literatury przedmiotu z zakresu rynku pracy artystów i twórców oraz ich finansowania.

Wnioski - Sektor kultury, a tym samym artyści i twórcy będący na rynku pracy w Polsce stanowią nie tylko ważna grupę społeczna, ale także ważny element gospodarki. Finansowanie twórców i artystów w Polsce wydaje się, że nie jest wystarczające, zważywszy na ich wkład w gospodarkę kraju.

Słowa kluczowe: artyści, twórcy, finansowanie działalności kulturalnej

\section{CONDITIONS OF FINANCING OF CREATORS AND ARTISTS IN POLAND}

\section{Summary}

Purpose - The aim of the considerations is to analyze the financial and economic situation of artists and creators in Poland, paying particular attention to the forms of employment and welfare measuress.

Research method - The article is a review of various historical sources presenting the situation and determinants of financing creators and artists in Poland since 2010. The article uses a critical analysis of the literature on the subject of the labor market of artists and creators and their financing.

Results - The cultural sector, and thus artists and creators who are on the labor market in Poland, are not only an important social group, but also an important element of the economy. Funding creators and artists in Poland seems to be insufficient, considering their contribution to the country's economy.
\end{abstract}

1 Artykuł wpłynął 8 sierpnia 2018 r., zaakceptowano 6 maja 2019 r.

Article received 8 August 2018, accepted 6 May 2019. 
Key words: artists, performers, financing artistic activities

JEL Classification: Z10, M54

\section{Wstęp}

Kultura, a także artyści i twórcy, stanowią istotną grupę społeczną. Znaczenie gospodarcze, ekonomiczne i finansowe sektora kultury w Polsce stopniowo wzrasta. Sposoby finansowania kultury zmieniały się na przestrzeni wieków, lecz zawsze zaangażowanie sektora publicznego/państwowego w działalność kulturalną było znaczne. Większość państw w Europie przejęła odpowiedzialność za finansowanie kultury. Warto zadać pytania: Czy artyści są dobrze wynagradzani? Co stanowi ich główne źródło utrzymania? W jaki sposób będzie finansowana działalność kulturalna w Polsce w przyszłości? Czy będą wprowadzone jakieś zmiany systemowe?

Związek między kulturą a państwem ma bardzo długą tradycję, podobnie jak zaangażowanie sektora publicznego w działalność kulturalną. W wieku XIX, mimo często zmieniających się rządów, większość państw przyjęła zasadę przejęcia odpowiedzialności za kulturę i jej finansowanie. Wszyscy byli zgodni, że celem państwa jest kontynuowanie, poparcie i nadzór władz państwowych nad wysiłkami oświecenia i kultywacji społeczeństw związanych z „rozwojem i rozpowszechnianiem kultury" [Bauman, 2011, s. 118].

W XX w. (po raz pierwszy w historii) doszło do zakładania specjalnych Ministerstw do spraw kultury, których zadaniem było dbanie o narodowe dziedzictwo, pielęgnacja i udostępnianie obywatelom dzieł kultury w celu obrony ich tożsamości i spójności narodowej oraz tworzenie jednolitych programów kulturowych [Bauman, 2011, s. 119].

Artykuł ma charakter przeglądu różnych źródeł historycznych przedstawiających sytuację i uwarunkowania finansowania twórców i artystów w Polsce od 2010 r. W artykule zastosowano analizę krytyczną i opisową oraz analizę literatury przedmiotu z zakresu rynku pracy artystów i twórców oraz ich finansowania.

\section{Określenie sektora kultury}

Sektor kultury jest jednym z najbardziej istotnych składników europejskiej i światowej przestrzeni społecznej i ekonomicznej, który jednocześnie, jak pisze K. Żak [2017, s. 10], absorbuje i katalizuje rozwój technologii informacji i komunikacji, a kultura to jeden z głównych czynników rozwoju społecznego i ekonomicznego każdego kraju. Kultura to zbiór właściwych dla społeczności koncepcji prawdy, dobra, piękna i efektywności, przekazywany w procesach socjalizacji i wychowania, przejawiających się w stylach życia jej uczestników [Schweder, 2003, s. 256]. Pod pojęciem „,kultura”, jak pisze A. Kaliszewski [2012, s. 13], rozumie się: „jeden z najbardziej popularnych terminów humanistyki i nauk społecznych [...], to 
wytrych słowny, po który sięga się w dyskursie publicznym, niemal za każdym razem mając na myśli coś innego".

Kultura, jako całokształt duchowego i materialnego dorobku ludzkości [Michalczuk, 2013, s. 75] gromadzonego, utrwalanego i wzbogacanego w ciagu jej dziejów, przekazywanego z pokolenia na pokolenie, jest sektorem, który wymaga dużego nakładu finansowego. Dobra i usługi kultury tworzą i dostarczają społeczeństwu trzy grupy podmiotów: publiczne, pozarządowe (non profit) oraz przemysł kultury, które współdziałając ze sobą wzajemnie się uzupełniaja. W Polsce wśród wszystkich instytucji prowadzących działalność kulturalną dominuja publiczne instytucje kultury, co wskazuje na potrzebę zmian w obszarze regulacyjnym [Ignatowski, Wójcik-Jurkiewicz, 2016, s. 137]. Działanie publicznych instytucji kultury w Polsce określa Ustawa o organizowaniu i prowadzeniu działalności kulturalnej [Ustawa..., 2001].

Zgodnie z wymienioną ustawą działalność kulturalną mogą prowadzić osoby prawne, osoby fizyczne oraz jednostki organizacyjne nieposiadające osobowości prawnej. Formami organizacyjnymi działalności kulturalnej w świetle ustawy są w szczególności: teatry, opery, operetki, filharmonie, orkiestry, instytucje filmowe, kina, muzea, biblioteki, domy kultury, ogniska artystyczne, galerie sztuki oraz ośrodki badań i dokumentacji w różnych dziedzinach kultury [Wójcik-Jurkiewicz, Karczewska, 2017, s. 172].

\section{Monitorowanie pracy artystów w Polsce i za granicą}

W Polsce nie ma tradycji monitorowania i analizowania rynku sektora kultury, rynku pracy artystów, twórców, ani organizacji kulturalnych. W polskiej literaturze można znaleźć publikacje, które podejmowały problem zatrudnienia i wynagrodzenia twórców, sytuacji rynkowej artystów czy też poziomu ich przedsiębiorczości. Nie jest to jednak znacząca ilość polskich opracowań poruszających tematy związane $z$ rynkiem pracy dla artystów i twórców.

Dane z Głównego Urzędy Statystycznego (GUS) wykorzystano m.in. w raporcie Rynek pracy w kulturze 1998-2002 [Słaby, 2005] oraz w Statystyce kultury Eurostatu [www 1]. Powstały także opracowania dotyczące rynku pracy artystów w sektorach kreatywnych, do których zalicza się: Znaczenie gospodarcze sektora kultury - wstęp do analizy problemu [Lewandowski i in., 2010], Sektor kreatywny w województwie pomorskim i kujawsko-pomorskim [Grochowski i in., 2012] oraz Potencjat malopolskich przemystów kreatywnych [Gałka i in., 2012].

Pierwsze badanie sytuacji ekonomicznej artystów zostało wykonane na zlecenie Australijskiej Rady Sztuki w 1981 r. przez zespół pod kierownictwem D. Throsby'ego z Masquarie University [Throsby i in., 1983]. Raport ten wprowadził jako pierwszy definicje ,praktykującego profesjonalnego artysty”, rozróżnienie ścieżek kariery artystów i oszacowanie ich przychodów.

Do ważniejszych opracowań zagranicznych, opisujących sytuację rynkową artystów i twórców, możemy zaliczyć następujące raporty: Creative Artists, Market 
Development and State Policies [2001] oraz The Status of Artists in Europe [2006]. Raporty te stanowiły przegląd działań na rzecz wsparcia artystów i twórców w poszczególnych krajach oraz wskazywały na innowacyjne rozwiązania mające na celu poprawę sytuacji artystów na rynku pracy. Zwłaszcza ten drugi - zrealizowany na zamówienie Parlamentu Europejskiego - podjął temat rozwiązania sytuacji ekonomiczno-społecznej artystów z państw członkowskich, uznania ich znaczenia osobistego i ich działalności dla integracji europejskiej oraz poprawy ich statusu czy warunków pracy.

Zbiór danych na temat rynku pracy artystów i twórców zawiera portal Compendium of Cultural Policies and Trends in Europe [Compedium...]. Stanowi on źródło aktualnych informacji z 41 krajów europejskich dotyczące prawa podatkowego oraz zabezpieczeń socjalnych dla artystów obowiązujących w tych krajach.

\section{Dane statystyczne dotyczące zatrudnienia artystów i twórców w sektorze kultury}

Zatrudnienie w sektorze kultury oraz w tzw. „zawodach kulturalnych” w Europie w 2002 r. wynosiło około 2,5\% ogółu zatrudnionych w całej gospodarce. Natomiast w 2009 r. w 27 krajach członkowskich UE w sektorze kultury, w pięciu najważniejszych działach (czyli w: działalności wydawniczej, produkcji filmowej, video i telewizyjnej oraz rejestracji dźwięku i działalności fonograficznej; radiofonii i telewizji, sztuce i działalności rozrywkowej; bibliotekach, muzeach, archiwach i innej działalności kulturalnej) zatrudnionych było 3,6 mln ludzi, co stanowiło 1,7\% całkowitego zatrudnienia. Badanie Eurostatu z 2011 r. pokazało, iż w grupie pisarzy, artystów i twórców (ISCO 245) pracowało $1,48 \mathrm{mln}$ ludzi, czyli 0,7\% całkowitego zatrudnienia mieszkańców Europy [Rynek pracy artystów..., 2013, s. 64-65].

Sektor kultury stanowi, powołując się na definicję ESS-net Culture, jeden z mniejszych sektorów polskiej gospodarki [Baran, Lewandowski, 2017, s. 18]. W latach 1998-2002 w Polsce nastapił nieznaczny wzrost zatrudnienia w sektorze kultury, zwłaszcza w małych firmach prowadzących działalność kulturalną, do którego zalicza się (według GUS) 22 grupy działalności zawodowej artystów, wliczając działalność wydawnicza, rekreacyjna, rozrywkowa, artystyczna, literacka, również działalność bibliotek i archiwów [Raport o stanie kultury, 2009, s. 6]. Proces urynkowienia w sektorze kultury w 2002 r. przedstawiał się następująco: 44\% sektor prywatny, $35 \%$ sektor publiczny i $21 \%$ trzeci sektor (non-profit). Świadczy to o zmianie charakteru finansowania kultury z instytucji subsydiowanych ze środków publicznych na instytucje poddawane regułom wolnego rynku. Liczba organizacji i przedsiębiorstw zajmujących się kulturą wśród trzeciego sektora systematycznie się zwiększała i w $2010 \mathrm{r}$. wynosiła 14\% wszystkich organizacji tego typu $(32 \%$ z nich prowadziło działalność sceniczna, teatralną, muzyczną albo kinematograficzną [Jagodzińska, 2013a, s. 156-157]. Ponadto prawie 60\% firm i podmiotów działajacych w kulturze powstało po roku 1989 i są to przeważnie małe jednostki gospodarcze zatrudniające do 5 osób. 
Według GUS w Polsce zatrudnienie w sektorze kultury, w podmiotach prowadzących działalność gospodarczą zatrudniających powyżej 9 osób, wyniosło w 2002 r. 1,8\% ogółu zatrudnionych, a liczba pracujących w sektorze kultury stanowiła 1,2\% wszystkich pracujących [Słaby, 2005, s. 12-13]. Liczba podmiotów gospodarczych prowadzących działalność twórczą w 2010 r. wyniosła powyżej 26 tys. podmiotów gospodarczych. Do 2013 r. liczba ta wzrosła do 35 tys. przedsiębiorstw działających w sektorze kultury. Przeciętne zatrudnienie wyniosło trzy osoby na jedno przedsiębiorstwo [Baran, Lewandowski, 2017, s. 31].

Do 2010 r. w sektorze kultury pracowało około 2,5\% ogółu pracujących (260 tys. zatrudnionych), a w przemysłach kreatywnych - 2,7\% (375 tys. zatrudnionych). Z tej grupy najliczniej reprezentowana była sekcja działalności artystyczno-kulturalnej, w której pracowało 47\% osób ogólnie zatrudnionych w sektorze kultury. Co trzeci przedstawiciel zawodów artystycznych i twórczych zatrudniony był w zakładzie pracy zatrudniającym od 100 do 249 osób [Rynek pracy artystów..., 2013, s. 326].

Zatrudnienie w sektorze kultury w Polsce 2015 r. wzrosło do blisko 300 tys. osób, co stanowiło 1,9\% wszystkich pracujacych w polskiej gospodarce. Sektor kultury stanowił 1,7\% PKB, lecz niestety udział kultury w wartości dodanej dla całej gospodarki spadł z 2,4\% w 2008 r. do 1,9\% w 2017 r. Wartość dodana sektora kultury w 2015 r. stanowiła około $22,7 \mathrm{mld}$ zł, natomiast w sektorze przemysłów kreatywnych wynosiła 42,6 mld zł. Udział sektora kultury i przemysłów kreatywnych w PKB zmniejszył się z 2,9\% PKB w 2008 r. do 2,4\% w 2015 r. [Baran, Lewandowski, 2017, s. 37].

W 2010 r. w podmiotach gospodarczych o liczbie pracujących przekraczającej 9 osób zatrudnionych było 9,7 tys. „artystów i twórców”, z czego najliczniejszą grupę stanowili kompozytorzy, artyści muzycy i śpiewacy (ponad 5 tys.). Druga co do liczebności grupę stanowili aktorzy (1,9 tys.), trzecią zaś - artyści plastycy (około 1 tys.) [Rynek pracy artystów..., 2013, s. 279].

W latach 2008-2014 artyści i twórcy zatrudniani byli głównie w sektorze publicznym (60\% to kompozytorzy, artyści muzycy i śpiewacy; 22\% aktorzy, 8\% choreografowie i tancerze), zaś artyści plastycy, reżyserzy i producenci, projektanci oraz prezenterzy radiowi i telewizyjni w sektorze prywatnym. Struktura zatrudnienia w 2015 r. przedstawiała się inaczej. Największa grupa 75 tys. (czyli 1/4 wszystkich zatrudnionych w kulturze) zajmowała się przedstawieniami artystycznymi, twórczością literacką i pracuje w obiektach kultury. Działalność architektoniczna była reprezentowana przez 37 tys. osób, a agencje reklamowe - które zajmowały trzecią pozycję - przez 30 tys. osób. Zatrudnienie przekraczające 15 tys. osób było widoczne w branżach, takich jak wydawanie książek, telewizja, produkcja i dystrybucja filmów, biblioteki i archiwa oraz muzea. Branże te skupiały łącznie 4/5 zatrudnionych w sektorze kultury. Największa ekspansja zatrudnienia w latach 2008-2015 była widoczna m.in. w takich branżach, jak projektowanie specjalistyczne, biura architektoniczne, agencje reklamowe, fotografia, przedstawienia artystyczne i produkcja programów telewizyjnych. 
W latach 2008-2015 województwo mazowieckie nadal było miejscem skupiającym większość działalności kulturalnej w kraju oraz $1 / 3$ zatrudnionych w kulturze (88 tys. osób, czyli $29 \%$ wszystkich osób pracujących w sektorze kultury). Udział wszystkich osób zatrudnionych/pracujących w sektorze kultury jest w tym województwie najwyższy i stanowi 3,2\% [Baran, Lewandowski, 2017, s. 19-26]. W Polsce większość działań skupionych jest $\mathrm{w}$ Warszawie, grupa ta stanowi $1 / 4$ wszystkich zatrudnionych w tym segmencie rynku. Liczba pracujących w Warszawie stanowiła w 2002 r. około 12,8\% ogółu pracujących w Polsce i także tam (czyli w województwie mazowieckim) można było zaobserwować najwyższe wynagrodzenie w sektorze kultury [Rynek pracy artystón..., 2013, s. 23].

\section{Sytuacja artystów i twórców na rynku pracy w Polsce}

Raport ZASP z 2015 r. [Szulborska-Lukaszewicz, 2015, s. 208-210] oraz Raport D. Ilczuk z 2013 r. [Rynek pracy artystów..., 2013], dotyczące sytuacji finansowej artystów i twórców scen polskich, uwidocznił, iż zawód artysty scenicznego w 2013 r. charakteryzował się dużą niepewnością, przejawiającą się m. in.:

1. Niskimi, nie zawsze regularnymi przychodami artystów. W przypadku freelancerów wiązało się to często z długimi okresami bez żadnych dochodów, co uniemożliwiało im samodzielne opłacanie składek na ZUS i NFZ (około 40\% respondentów zarabiała między 1700 a $2050 \mathrm{zł}$ brutto miesięcznie, kolejne $17 \%$ poniżej $1500 \mathrm{zł}$ ). Wynagrodzenia artystów pracujących 5 czy 20 lat niewiele się od siebie różniły, a przychody artystów - niezależnie od stażu pracy - były niższe w stosunku do średniej krajowej.

2. Niestabilnością zatrudnienia: umowy na czas określony, umowy o dzieło, zlecenia, zatrudnianie artystów na okres 10 miesięcy w roku z pominięciem okresu wakacji.

3. Małą zaradnością artystów na rynku pracy oraz niską skutecznością poszukiwania dodatkowych źródeł przychodu. Artyści nie radzili sobie na rynku pracy, nie byli przygotowani do podejmowania działalności gospodarczej, nie stać ich było na zatrudnienie agenta. Byli często wykorzystywani, ponieważ zmuszeni sytuacją materialną skłonni byli pracować za bardzo niskie wynagrodzenia. Artystom brakowało wiedzy z zakresu identyfikacji źródeł finansowania swojej działalności artystycznej. Mieli oni także niewielkie umiejętności w zdobywaniu dostępu do informacji na temat grantów, stypendiów ministerialnych, samorządowych oraz fundowanych przez fundacje i stowarzyszenia.

4. Deficytem systemowych rozwiązań gwarantujących minimalne zabezpieczenia socjalne (ubezpieczenia socjalne i emerytalno-rentowe) dla artystów. Od lat nie wprowadzono żadnych zmian $\mathrm{w}$ zakresie rozbudowy instrumentów ochrony praw socjalnych artystów. Niezależni artyści byli prawdopodobnie w naszym kraju ,największą czynna grupa zawodowa pozbawioną dostępu do opieki zdrowotnej. 
5. Niewystarczającymi kompetencjami menedżerskimi z zakresu przedsiębiorczości i autopromocji. Potrzebę przedsiębiorczych postaw artystów na rynku pracy potwierdziły przede wszystkim rozmowy z artystami, którzy wśród niedostatków programów kształcenia na studiach artystycznych wymieniali brak przedmiotów ułatwiających „,kreowanie wizerunku”, ,zarządzanie własną karierą", promowanie siebie oraz sprawne poruszanie się na rynku pracy.

6. Brakiem wsparcia dla artystów ze strony władz państwowych i pozarządowych, niskiej skali wsparcia bezpośredniego w postaci grantów, stypendiów, nagród czy też dotacji do projektów. Około 63\% artystów i twórców w Polsce negatywnie oceniała wsparcie ze strony państwa skierowane w stronę artystów. Najczęściej oczekiwania pod adresem pomocy państwowej formułowali muzycy i tancerze.

7. Dostatecznym (37\%) bądź złym (53\%) dostępem do informacji o ofertach pracy i wolnych angażach dla artystów. Informacje uzyskiwane były najczęściej od kolegów (51\%), reżyserów i agentów (około 21\%-23\%), przez udział w castingach $(27 \%)$ lub przez Internet $(20 \%)$.

8. Niewłaściwymi rozwiązaniami, uniemożliwiającymi artystom-wykonawcom kształcenie ustawicznie i ewentualne przekwalifikowanie ${ }^{2}$.

Raport J. Szulborskiej-Łukaszewicz [2015, s. 18] podkreśla konieczność stworzenia systemu ubezpieczeń zdrowotnych i zabezpieczeń emerytalnych, dostosowanego do specyfiki zawodów artystycznych. Kolejną rekomendacją raportu jest konieczność wspierania i rozwoju pracy artystów m.in. poprzez szkolenia i wykorzystanie funduszy samorządowych, tworzenie nowych miejsc pracy, a także przeciwdziałanie dalszej destabilizacji zawodu artysty.

Sami artyści i twórcy zwracają uwagę na ich niedostatki edukacyjne, zwłaszcza w obszarze nabywania umiejętności związanych z: podstawową wiedzą z zakresu przedsiębiorczości, zarządzania i ekonomii; wiedzą z zakresu prawa autorskiego i praw pokrewnych oraz prawa własności intelektualnej; poznaniem rynku pracy i umiejętnością poruszania się na nim; realizacją projektów kulturalnych i umiejętnością składania wniosków grantowych/unijnych itp. [Kaczmarek, Posłuszna, 2018b, s. 143].

Artyści i twórcy w Polsce mają świadomość własnych braków edukacyjnych, zwłaszcza w obszarze nabywania umiejętności związanych z podstawową wiedzą w zakresie przedsiębiorczości - poznaniem rynku pracy i umiejętnością poruszania się na nim, zarządzania i ekonomii oraz zarządzania własną karierą [Kaczmarek, Posłuszna, 2018, s. 22]. Absolwenci z krajów europejskich deklarują, że chcieliby mieć większą wiedzę po ukończeniu studiów w zakresie funkcjonowania rynku pracy. Może to oznaczać, że uniwersytety akademickie przygotowują swoich

2 Warto nadmienić, że Instytut Muzyki i Tańca (IMIT) prowadził przykładowo od 2016 r. „Program wsparcia przekwalifikowania zawodowego tancerzy" w departamencie tańca skierowany do profesjonalnych tancerzy. Celem programu jest wsparcie tancerzy tańca artystycznego w procesie zdobywania kwalifikacji zawodowych i doświadczenia, niezbędnych do rozpoczęcia drugiej ścieżki kariery zawodowej, po zakończeniu kariery scenicznej [www 6]. 
absolwentów przede wszystkim pod względem artystycznym, ale studenci nie mają przedmiotów, które poruszałyby na studiach kwestie dotyczące prawa, marketingu czy psychologii [Kaczmarek, 2017, s. 49]. Sytuacja ta wskazuje na pilną konieczność wprowadzania szybkich zmian w polskim systemie edukacji artystycznej w celu dostosowania programów nauczania i kształcenia do wymogów i realiów współczesnego rynku pracy.

Przez ostanich pięć lat wyraźnie widać, że artyści i twórcy zaczęli się organizować we współczesnym systemie pracy prekarnej. W Polsce swoją karierę zawodowa, pracując $\mathrm{w}$ charakterze freelancerów, kontynuuje wielu artystów. Wolni strzelcy, często wykształceni specjaliści, którzy nie posiadają stałych umów z instytucjami, stają się prekariuszami. Są zatrudniani na podstawie umów na krótki czas i żyją od umowy do umowy, w braku stabilności, w niepewności i mimo, że to oni sa twórcami sztuki, poświęcając swój czas i środki na ten cel, to tylko niewielki procent budżetów przeznaczonych na kulturę trafia do jej rzeczywistych wytwórców, tym samym nie posiada zabezpieczeń socjalnych [www 2]. Niskie zarobki i nieregularność dochodów powoduje, że artyści szukaja dodatkowych form zatrudnienia czy zleceń. Niewattpliwie ta grupa zawodowa jest narażona na duży stres wynikający ze specyfiki wykonywanej pracy [www 3; Kaczmarek, Posłuszna, 2018a].

Artyści scen polskich opowiadają się za stabilizacją w sferze zatrudnienia i posiadaniem minimalnych, ale przewidywalnych przychodów (72\%) oraz poczuciem bezpieczeństwa w zakresie ochrony zdrowia [Szulborska-Łukaszewicz, 2015, s. 95]. Najbardziej satysfakcjonującą kwotą miesięcznych przychodów dla około $45 \% \mathrm{z}$ nich stanowią zarobki $\mathrm{w}$ wysokości $4000-5000$ zl na miesiąc. Warto przypomnieć, że przeciętne zarobki w zawodach kultury wynosiły w 2014 r. około 3000-3500 zł/miesiąc.

\section{Podsumowanie}

Życzeniem wielu środowisk, nie tylko samych zainteresowanych, jest zmiana sytuacji artystów na rynku pracy w Polsce, co z cała pewnością przyczyni się do wzmocnienia statusu artysty w naszym kraju. Dyrektor Zachęty Narodowej Galerii Sztuki H. Wróblewska przyznała, że problemów artystów nie można bagatelizować „Artysta jest dziś w wyjątkowej sytuacji - ni pies, ni wydra. Cały czas jest artysta, ale zarabia tylko od czasu do czasu" [www 4]. Artyści i twórcy tworzą kapitał ludzki wnosząc do kultury swój talent, zdolności, umiejętności i wiedzę [Berniak-Woźny, Wilks, 2017, s. 12]. Innowacyjność i kreatywność są cennymi atrybutami artystów, dlatego kapitał ludzki to istotne aktywa każdego społeczeństwa [Wójcik-Bubała i in., 2017, s. 322]. Nowocześni artyści prowadzą zmagania na dwóch frontach, z jednej strony przedstawiaja się odbiorcom, jako nonkonformiści, a $z$ drugiej zapewniają rynek, że warto ich sprzedać. Badania prowadzone w ostatniej dekadzie przez psychologów wykazały, że nonkonformizm artystów wzbudza zainteresowanie nie jednej wybranej grupy, ale właściwie wszystkich warstw społecznych. Przyczyn takiej popularności należałoby szukać w wirtualnej rzeczywistości kreowanej przez media. Nonkonformizm jest nieszkodliwy, gdyż przypatrując się jego funkcjonowaniu, 
zasięgowi oraz wpływom widać, że nie jest w stanie naruszyć podstaw funkcjonowania mechanizmu społecznego [Posłuszna, 2008a, s. 82]. Grupa artystów zawdzięcza państwu edukację, co oczywiście przynosi zyski, jak i ma swoje koszty. Sa nimi, rzecz jasna, inwestycje poniesione na ich edukację, a niewattpliwym zyskiem odpowiednio wykwalifikowani ludzie, ich twórcze inicjatywy i dzieła, którymi dzielą się z resztą społeczeństwa [Wójcik-Jurkiewicz, 2011, s. 326]. Przysposabianie jednostki do życia w społeczności poprzez muzykę, poezję, sztukę, naukę otrzymało filozoficzne, jak wskazywał W. Jaeger w swym słynnym dziele Paideia, uzasadnienie; ugruntowało ono niespotykaną na żadną skalę rolę wychowania [Posłuszna, 2008, s. 31]. Grupa twórców i artystów najczęściej wyznacza nowe prądy i idee. W większości dostępnych publikacji przyjmuje się, że w model kapitału ludzkiego wpisuje się twórczą i kreatywną chętną do rozwoju, doskonalenia i podejmowania nowych wyzwań naturę człowieka [Wójcik-Jurkiewicz, 2011, s. 321]. Zaobserwować można wyraźne luki również w obecnej polityce rządowej, odnoszące się zarówno do kwestii podażowych (szkolnictwo artystyczne), jak i popytowych (skala wsparcia bezpośredniego dla artystów, ulgi podatkowe, poziom edukacji kulturalnej, niski udział społeczeństwa w kulturze). Rysujący się obraz rynku zawodowego artystów pozwala ostrożnie wnioskować, że w przyszłości sytuacja ta nie ulegnie zmianie na lepsze. „Zawodowa sytuacja twórców i artystów w Polsce nie jest adekwatna do rozpoznanych tendencji rozwojowych, zgodnie z którymi kultura i jej przemysły zostały uznane za nowy obszar inwestowania, źródło kreatywności i innowacyjności" [Rynek pracy artystów..., 2013, s. 21]. Finansowanie twórców i artystów w Polsce nie jest wystarczające, zważywszy na ich wkład w gospodarkę kraju [www 5].

Nowa formą finansowania kultury jest tworzenie przemysłu kultury, który oferuje wiele miejsc pracy poza sektorem publicznym. Tym, co charakteryzuje przemysł kultury jest wysoki poziom innowacyjności, kreatywności, zakotwiczenie w regionie oraz przewaga małych i średnich firm, które wytwarzają usługi i dobra kulturalne o charakterze komercyjnym. Przemysł kultury jest reprezentowany przez różne jednostki gospodarcze m.in. audiowizualne, muzyczne, artystyczne, wydawnicze, filmowe, modowe czy też reklamowe. Kolejnym miejscem realizacji działań artystycznych może być w Polsce sektor kreatywny, który nadal ma bardzo duży potencjał, ale w dalszym ciagu jest mało rozpoznanym rynkiem pracy dla artystów w części obejmującej przemysły kultury. Sektor kreatywny bowiem stanowi branżę, która stawia na indywidualne umiejętności, talent, potencjał, kreatywność i innowacyjność oraz łączy twórczość, produkcję i komercjalizację zarazem.

\section{Literatura}

Baran J., Lewandowski P., 2017, Znaczenie gospodarcze sektora kultury w Polsce w latach 2008-2015, Instytut Badań Strukturalnych, Warszawa.

Bauman Z., 2011, Kultura w plynnej nowoczesności, Narodowy Instytut Wizualny, Warszawa. 
Berniak-Woźny J., Wilks D.C., 2017, The Role of CSR In Corporate Social Capital Creation, "Business and Non-profit Organizations Facing Increased Competition and Growing Customers' Demands", vol. 16, pp. 11-27.

Compendium of Cultural Policies and Trends in Europe, www.culturalpolicies.net [data wejścia: 28.12.2016].

Creative Artists, Market Development and State Policies, 2001, Raport Europejskiego Instytutu Badawczego ERICarts, Bonn.

Gałka J., Grodny S., Olszewska D., Tompolska A., 2012, Potencjał matopolskich przemystón kereatywnych, Narodowe Centrum Kultury, Kraków, https://www. obserwatorium.-malopolska.pl/wp-content/uploads/2016/05/Przemys $\% C 5 \%$ 82y_-kreatywne.pdf [data wejścia: 20.12.2016].

Grochowski M., Dudek-Mańkowska S., Fuhrmann M., Zegara T., 2012, Sektor kreatywny w wojewódžtwie pomorskim $i$ kujawsko-pomorskim. Raport z badan, Agencja Rozwoju Pomorza S.A., Gdańsk.

Ignatowski R., Wójcik-Jurkiewicz M., 2016, Raportowanie spótek w zakeresie społecznie odpowiedzialnego biznesu, [w:] Instrumenty polityki spotecznej, Ignatowski G., Sułkowski L., Dobrowolski Z. (red.), Difin, Warszawa, s. 124-142.

Jagodzińska J., 2013, Charakterystyka driatalności kulturalnej w Polsce po transformacii ustrojowej, [w:] Kultura a rozwój, Hausner J., Karwińska A., Purchla J. (red.), Narodowe Centrum Kultury, Warszawa, s. 127-160.

Jagodzińska K., 2013a, Szkolnictwo artystyczne i sytuacja artysty w Polsce, [w:] Kultura a rozwój, Hausner J., Karwińska A., Purchla J. (red.), Narodowe Centrum Kultury, Warszawa, s. 161-174.

Kaczmarek S., 2017, Professional path of musician graduating from college in Europe mainly of Germany, England and Poland, [w:] Professional musician: between art, education and management, Sternal M. (red.), Akademia Muzyczna, Kraków, s. 27-54.

Kaczmarek S., Posłuszna J., 2018, Culture and its Creators - Challenges and Financial Issues, „Zeszyty Naukowe Wyższej Szkoły Finansów i Prawa w Bielsku-Białej”, nr 2, s. 20-23, DOI: 10.5604/01.3001.0012.4272.

Kaczmarek S., Posłuszna J., 2018a, Forms of financing the cultural sector in Poland against the background of solutions from selected European countries, „Zeszyty Naukowe Wyższej Szkoły Finansów i Prawa w Bielsku-Białej", nr 4, s. 11-16, DOI: 10.5604/01. 3001.0013.0386.

Kaczmarek S., Posłuszna J., 2018b, Marzenia a ržeczywistość - kariery wspótczesnych musyków, „Annales”, vol. 30, no. 1, Sekcja „J”, s. 132-147, DOI: 10.17951/j.2018. 31.1.133-147.

Kaliszewski A., 2012, Glówne nurty w kulturze XX i XXI wieku, Wydawnictwo Poltext, Warszawa.

Lewandowski P., Mućk J., Skrok L., 2010, Znaczenie gospodarcze sektora kultury - wstęp do analisy problemu. Raport końcony, Instytut Badań Strukturalnych, Warszawa.

Michalczuk G., 2013, Zasoby niematerialne jako çynnik wartości przedsiębiorstwa. Luka informacyjna sprawozdawczości finansowej, Wydawnictwo Uniwersytetu w Białymstoku, Białystok. 
Posłuszna J., 2008, Muzyka i jej korz̨enie, [w:] Pomięzy wpływem społecznym a manipulacja, Kwiatkowska G.E. (red.), Wydawnictwo UMCS, Lublin, s. 29-40.

Posłuszna J., 2008a, Nonkonformizm sz̧tuki na lawie oskarżonych, [w:] Niezależni $i$ ulegli. Studia o nonkonformizmie, Bernacka R.E. (red.), Wydawnictwo Adam Marszałek, Toruń, s. 81-90.

Raport o stanie kultury, 2009, Fatyga B. (red.), Ministerstwo Kultury i Dziedzictwa Narodowego, Warszawa.

Rynek pracy artystów i twórców w Polsce. Raport z badań, 2013, Ilczuk D. (red.), Ministerstwo Kultury i Dziedzictwa Narodowego, Bydgoszcz-Warszawa.

Schweder R.A., 2003, Mapy zasad moralnych, zarozumiatość pierwszego swiata i nowi ewangelisci, [w:] Kultura ma znaczenie. Jak wartości wplywaja na rozwój spoleczeństw, Harisson L.E., Huntington S.P. (red.), Zysk - S-ka, Poznań, s. 250-272.

Słaby T., 2005, Rynek pracy w kulturze 1998-2002, Instytut im. Adama Mickiewicza, Warszawa.

Szulborska-Łukaszewicz J., 2015, Artysto Scen Polskich, powiedz nam z çego żyjesz...?, ZASP - Stowarzyszenie Polskich Artystów Teatru, Filmu, Radia i Telewizji, Kraków.

The Status of Artists in Europe. Culture and education, 2006, Raport Europejskiego Instytutu Badawczego European Institute for Comparative Cultural Research (ERICarts), Bonn.

Throsby D., Thompson B., Whiters G., 1983, Measuring Community Benefits from the Arts Research Paper 261, Masquarie University, Sydney.

Ustawa o organizowaniu i prowadzeniu działalności kulturalnej z 25 października 1991 r., Dz.U. 2001, nr 13, poz. 123 z pózn. zm.

Wójcik-Bubała J., Jacenko M., Wójcik-Jurkiewicz M., 2017, The importance of accountability for innovation development viewed through the mediating role of intellectual capital, "Business and Non-profit Organizations Facing Increased Competition and Growing Customers' Demands”, vol. 16, pp. 319-331.

Wójcik-Jurkiewicz M., 2011, Kapitat intelektualny w teorii $i$ praktyce rachunkowości, „Zeszyty Naukowe Uniwersytetu Szczecińskiego. Finanse, Rynki Finansowe, Ubezpieczenia”, nr 41, s. 321-329.

Wójcik-Jurkiewicz M., Karczewska M., 2017, Możliwości wspótpracy biznesu z.jednostkeami kultury w aspekcie zastosowań nowych technologii, [w:] Biznes w kulturze - kultura $w$ biznesie. Nowoczesne technologie informacyjno-komunikacyjne, Reformat B., Kwiecień A. (red.), Wydawnictwo Uniwersytetu Ekonomicznego w Katowicach, Katowice, s. 171-180.

Żak K., 2017, Dostęp do kultury via technologie informacyjno-komunikacyjne: Polska na tle Unii Europejskiej, [w:] Biznes w kulturze - kultura w biznesie. Nowoczesne technologie informacyjno-komunikacyjne, Reformat B., Kwiecień A. (red.), Wydawnictwo Uniwersytetu Ekonomicznego w Katowicach, Katowice, s. 9-20.

www 1, http:/ /www.ideedlatanca.pl/ [data wejścia: 24.05.2019].

www 2, http:/ / wyborcza.pl/1,76842,14620493,Po_co_placic_artystom_Przeciez_

maja_promocje.html [data wejścia: 10.02.2018]. 
www 3, http://warszawa.wyborcza.pl/warszawa/1,34861,11768722,Dzien_bez_ sztuki_strajk_artystow.html [data wejścia: 10.02.2018].

www 4, http://wiadomosci.gazeta.pl/wiadomosci/1,114873,11774608,Uwaga strajk_artystow__Nawet_najbardziej_znanych.html [data wejścia: 10.02.2018]. www 5, http://ela.nauka.gov.pl/ [data wejścia: 24.05.2019]. 